\title{
ASTONIN ADDITION TO IMPROVE WARFARIN EFFICIENCY AGAINST M. MUSCULUS IN HOUSES AND FIELD HABITAT, BENI - SUEF GOVERNORATE
}

\author{
RIZK, A. M. \\ Plant protection Research Institute, ARC، Dokki, Giza.
}

(Manuscript received 31 May 2016)

\begin{abstract}
$\mathrm{I}$ $\mathrm{n}$ rodent control programs House mouse, Mus musculus appear high tolerance to anticoagulant rodenticide. So, susceptibility of $M$. musculus trapped from houses and vegetable field habitats at warfarin rodenticide bait alone or mix with astonin-H (Fludrocortisone) to improve the warfarin efficiency was tested in Beni-suef Governorate. Under laboratory conditions astonin addition to warfarin bait improve the mortality percent, with concentrate astonin, the mortality were $80 \%, 90 \%, 100 \%$ and $100 \%$ to warfarin bait $0.025 \%+0.1,0.25,0.5$ and $1.0 \%$ astonin respectively compared with warfarin bait $0.025 \%$ alone (50\%). Tested mice of M. musculus trapped from houses were susceptible to warfarin alone than trapped from fields the lethal feeding period, $\left(\mathrm{LFP}_{50}\right.$ and $\mathrm{LFP}_{90}$ ) to each treatment war $\left.4.8 \& 10.8\right)$ and $5.6 \&$ 15.0 day respectively. The $\mathrm{LFP}_{50}$ and $\mathrm{LFP}_{90}$ to warfarin bait + astonin decrease to $(3.2,6.3)$ and $(3.6,8.5)$ day to mice trapped houses and field compared with the same treatment with warfarin bait alone, all's, the time to death and bait consumptions reduced to near $40 \%$ with astonin addition. Under field conditions the population reductions were 86 and $91 \%$ in vegetable field and houses with warfarin bait $0.025 \%+$ astonin $0.25 \%$. In the same habitats warfarin bait $0.025 \%$ alone caused $64 \%$ and $68 \%$ reduction in population mice to each habitat respectively. So that the present work was directed to study the importance anticoagulant rodenticide treatment by addition astonin to improve the anticoagulant rodenticide efficiency, abate the quantity of using bait, control time and effort in rodent programs.
\end{abstract}

\section{INTRODUCTION}

In Egypt some sub-species of M. musculus distributed in many governorates fields and houses cause a large damage in crops and technological contents. Elapse time M.musculus appear more tolerant than other rodent species against anticoagulant rodenticide in programs control, (Hussein, 1997). Worldly, rodent tolerance or resistant observed as problem in many country and tested by Greaves et al, (1973); Deoras et al, (1972); Saunders (1978) and (Jackson and Ashton, 1980). This problem is due to a genetic and biochemical factors; food behavioral and habitat variety beside practical in rodent control. Buckle and Smith (1994) found that, green 
food stuffs mitigate the adverse effects of resistance and help resistant population to thrive in the absence of anticoagulant.

To avoid this problem many studies was directed to controlling resistant or tolerant rodent by improvement bait intake, modification anticoagulant rodenticide with using second generation as single dose (Khan et al, 2000). Addition some compound such as sulphaquinoxaline to kill the bacteria responsible for producing vit.k will enhance the action of anticoagulants, or this led to physiological effect and potentiate anticoagulant as calciferol, L-histidine, chloral hydrate, crude cardenolides and other (Meehan, 1984). Nowadays these problems consider the obstacle in rodent control and putting many questions around anticoagulant in future. So, this work aims to studs susceptibility of house mouse in two habitats and astonin efficacy, (Astonin, fludrocortisone acetate produce marked sodium retention and increased urinary potassium excretion, also causes arise in blood pressure) in addition to warfarin to overcoming tolerant or resistant.

\section{MATERIALS AND METHODS}

\section{Chemical:}

\subsection{Warfarin rodenticide:}

The first generation anticoagulant rodenticide, common names: warfarin, coumafene and zoo-comarin were used. Active ingredient (98\%) was obtained from "KZ pesticides company, Egypt". The bait of crushed maize $0.025 \%$ warfarin was prepared to use in treatments.

\section{2: Fludrocortisone:}

Fludrocortisone is sold under the brand name "Astonin- $\mathrm{H}$ " in Egypt as blood pressure drug. It was obtained from Amoun pharmaceutical company, Egypt as tablet (0.1mg Fludrocortisone). Tablets were powdered then add to warfarin bait $0.025 \%$ to prepare concentrations $1.0,0.5,0.25$, and $0.1 \%$ astonin as following:

- $\quad 100 \mathrm{gm}$ of warfarin bait $0.025 \%+1 \mathrm{gm}$ astonin

- $100 \mathrm{gm}$ of warfarin bait $0.025 \%+0.5 \mathrm{gm}$ astonin

- $\quad 100 \mathrm{gm}$ of warfarin bait $0.025 \%+0.2 \mathrm{gm}$ astonin

- $\quad 100 \mathrm{gm}$ of warfarin bait $0.025 \%+0.1 \mathrm{gm}$ astonin 


\section{2- Tested animals:}

House -mouse, $M$ musculus trapped from two area, houses and vegetable field, Beni-suef Governorate (El-Wasta district). The mice from each area transported to laboratory of Harmful Animals of Agriculture Res. Dep., Dokki Giza and caged individually for about two weeks with given a daily fresh supply of water and standard laboratory diet. A few days before the test each mouse weighted and given a reference number immature mice , pregnant females and mice that did not appear to be in good health were excluded from the test.

\section{Experiments:}

\subsection{Laboratory Experiments:}

Effect of astonin mixed with warfarin bait $0.025 \%$ against M. musculus was tested in this experiment by using the mortality percent and lethal feeding period.

\section{A. The mortality testes:}

Five grams of prepared baits, warfarin $0.025 \%$, warfarin $0.025 \%$ plus $0.1 \%$, $0.25 \%, 0.5 \%$ and $1.0 \%$ Astonin were offered in small container to each group, (10 individually caged mice) with free access of water daily. The bait consumption was recorded to seven day then mice feed on standard bait. Number of dead mice in each group, as well as the time to death ware recorded up to 21 day then the mortality percentage of mice was calculated.

\section{B. Lethal feeding period (LFP) determination:}

According to the method established by W.H.O. (1982) groups from ten mice trapped from houses were used to each feeding period. A series of feeding periods on warfarin bait $0.025 \%$ and warfarin bait $0.025 \%+0.25 \%$ Astonin ware conducted until feeding period reached cause $100 \%$ mortality. Through the feeding period the amount of eaten bait, as well as, the number of dead animals were recorded daily. After each animal group had undergone its selected feeding period, they were kept under the same condition prior to the test up to 28 days observation as a total length of the test. The same procedure was followed with the mice trapped from vegetable fields and the $\mathrm{LFP}_{50}$ and $\mathrm{LFP}_{90}$ were calculated. This method described by Finney (1971) the relationship between feeding period and mortality was evaluated and the lethal feeding period (LFP) was estimated. Also, the same calculation method was applied to estimate the lethal time to death 50 or $90 \%$ from treated mice (LT50 or LT 90$)$. 


\subsection{Field experiments:}

Warfarin bait $0.025 \%$ and warfarin bait $0.025 \%+0.025 \%$ Astonin used against M. musculus in houses and vegetable field, (ten houses and one Fadden) to each treatment with three replicate. The population density of house mouse was estimated pre and post treatment by food consumption method. Pre-treatment $25 \mathrm{gm}$ of wheat distributed on clay containers for five days and the total amount of wheat consumption calculated daily. The largest daily of wheat consumption was used as an index of the population size. Then $25 \mathrm{gm}$ of baits were distributed in clay containers for 7 days and the consumed bait amount was recorded after 14 days from the remaining of the baits, the same baiting procedure described for the pre-treatment census was run as index of the size of surviving population and from this and the pretreatment census index, the percentage of population reduction was calculated According to (Mathys, 1975) as the following equation:

Population reduction $\%=$

$$
\frac{(\text { pre-treatment.consumed })-(\text { post }- \text { treatment.consumed })}{\text { pre-treatment.consumed }} \times 100
$$

\section{RESULTS AND DISCUSSION}

\section{Astonin efficiency mixed with warfarin bait:}

Data concerning the effect of astonin concentrations mixed with warfarin bait against house mouse $M$ musculus summarized in table (1) the obtained data clear that, the mortality percent reach to $100 \%, 100 \%, 90 \%$ and $80 \%$ when astonin used at $1.0 \%, 0.5 \%, 0.25 \%$ and $0.1 \%$ mixed with warfarin bait $0.025 \%$, respectively, compare with $50 \%$ when mice feed on warfarin bait $0.025 \%$ alone. At the same time the total bait consumption /10mice decreased to $49.8 \mathrm{gm}, 53.6,57.4$ and $71.2 \mathrm{gm}$ to the same mixed respectively compare with $76 \mathrm{gm}$. From warfarin bait $0.025 \%$. So, the mean time to death decreased from 11 day with warfarin bait alone up to 5.0, 6.0, 7, and 9 day when mice treated with different warfarin mixtures respectively.

\section{1- Susceptibility of M. Musculus in different habitat to warfarin:}

Data in table (2) showed that after two day from feeding on warfarin bait $0.025 \%$ alone, the field mice group remains alive. But the mortality percentage was $30 \%$ in group feed on bait $(101 \mathrm{gm})$ for three days and time to death, (8 days). After feeding periods, mortality percentage increased progressively to reveal 60, 70, 90 and $100 \%$ through (5-18), (7-20), (7-17) and (6-19) days in groups with feeding for 6, 10, 
15 and 20 days and the bait intake were 157, 185.7, 192 and 201gm respectively. The $\mathrm{LFP}_{50}$ and LFP90 were 5.6 and 15.0 days.

Table (3) proved that warfarin bait $0.025 \%$ caused $10 \%, 20 \%, 60 \%, 90 \%$, $100 \%$ mortality through (0-5), (2-12), (4-14), (5-12) and (3-16) days after 2, 3, 6, 10 and 15 days after feeding of mouse trapped from houses and the mean bait intake were $45,72,130,172$ and 184gm to each feeding period respectively and LFP ${ }_{50}$ and LFP90 were 4.8 and 10.8 day.

Regarding the lethal feeding period values, $\mathrm{LFP}_{50}$ and $\mathrm{LFP}_{90}$ it showed higher with field mice (5.6 and 15.0 day) than houses mice (4.8 and 10.8 day), also the lethal time to death values ( $\mathrm{LT}_{50}$ and $\mathrm{LT}_{90}$ ) were 9.6 and 16.2 day to field mice compare with houses mice, 7.6 and 10.8 day. On the other hand field mice intake bigger amount of bait near to third part than houses mice. So, the obtained results showed that the mice trapped from houses proved susceptible than mice trapped from fields to warfarin. The susceptibility between tested area related to distinction food in field by vegetables and groups retch to different proteins and vitamins compare with house foods. Hussein (1997) found that Acomys cahirinus and Mus musculus exhibited a considerable tolerance to warfarin, while Arvicanthis niloticus was susceptible. The LD50 and LFP 50 were $422 \mathrm{mg} / \mathrm{kg}, 6$ day; $316 \mathrm{mg} / \mathrm{kg}, 5$ days and $62 \mathrm{mg} / \mathrm{kg}$ and 3.2 days to each species respectively. Kandil; et al (2008) under laboratory conditions clear that $R$. rattus group fed on poultry fodder should a relatively higher tolerance to warfarin than the other fed on vegetables or food stuffs, dry bread falafel and crushed maize, representing the dominant foods in houses) the $\mathrm{LFP}_{50}$ and LFP 90 values were (3.0 and 6) and (2.6 and 5.9) days for animals fed on vegetables and food stuffs, respectively.

\subsection{Potentiation of warfarin efficiency by adds astonin:}

Data in table (4) revealed that, after 15 day from feed on warfarin bait $0.025 \%+$ Astonin $0.25 \%$, all mice trapped from fields dead, (the days to death range were 1-13 day) and the mean intake bait through this feeding period were $122 \mathrm{gm}$. to10mice. The other feeding period 10, 6, 3 and 2 days cause 90, 80, 50, 50 and 10\% mortality percentage through (2-9), (1-13), (1-9) and (0-2) day to each feeding period after consumed 120,113, 85 and 31gm per ten mice respectively. The calculated $\mathrm{LFP}_{50}$ and $\mathrm{LFP}_{90}$ were (3.6 day) and (8.5 days). Anther hand the $\mathrm{LFP}_{50}$ and $\mathrm{LFP}_{90}$ when mice trapped from houses and feed on the same bait after different feeding period as it is in table (5) recorded (3.2 and 6.3 day respectively). After mice intake 30, 71, 95, and $100 \mathrm{gm} / 10$ mice through $2,3,6$ and 10 day the mortality percent were 10,60, 80 
and $100 \%$ and the time to death ranged between (0-2), (2-9), (1-8) and (1-9) day to each feeding period respectively.

The comparison results in table (6) showed the decrement of lethal feeding period (LFP) and lethal time to death (LT) values were 33\% and 35\% approximately, when mice feed on warfarin bait mixed with astonin compared with warfarin alone.

Discussing this results clear the astonin effect on warfarin efficiency, astonin lead to increase blood pressure and fast bleeding when add to warfarin bait. Jae (2011) indicated that the astonin-h drug containing active ingredient fludrocortisone and it is a mineralocorticoid with negligible glucocorticoid activity. The mineralocorticoid action is at level of the renal tubules where it promotes back absorption sodium and water and excretion of potassium. This will lead to migration water from the primary urine back to blood with increase in blood volume and interstitial tissue fluid. This increase in the interstitial sodium and water causes an increase in tissue turgor (pressure suit) and change in electrical potentials on the outer cell membrane which lead to increase vascular responsiveness to the circulating catechol amines.

\section{3- Field application:}

In houses and filed warfarin bait $0.025 \%$ mixed with astonin $0.025 \%$ successful to increasing the population reduction for M. musculus and the obtained data summarized in table (7). and The population reduction were $72 \%$ and $86 \%$ in treated field area by warfarin bait $0.025 \%$ and warfarin bait $0.025 \%+$ Astonin $0.25 \%$ and the bait consumption were $2.2 \mathrm{~kg}$ and $1.5 \mathrm{~kg}$ to each treatment while the treated houses mice consumed 1.7 and 1.0k.g from warfarin bait and warfarin bait mixed with astonin. The population reduction was 68 and $91 \%$ to each treatment. Hussein (1991) found that averages of population reduction were 68.3 and $71.6 \%$ for bromadiolone and brodifacaums respectively on M. musculus under field condition. Abel-Azeem (2013) clears that in Sharki governorate, El-Ibrahemia fields the population redaction were $90.31 \%, 71.95 \%$ and $84.40 \%$ for $A$. niloticus, M. musculus and $R$. norvegicus after treated by $0.0005 \%$ chlorophacinone + astonin $0.5 \% \mathrm{w} / \mathrm{w}$ bait comparative with chlorophacinone alone the redaction to each species were $83.01 \%, 62.64 \%$ and $78.05 \%$, respectively.

According to above results clear that, Aston addition to warfarin enhance the mortality percent of $M$. musculus in laboratory and reduce the population in field more than warfarin alone with reduce time to death and shorting the program period beside decreased the bait intake this all reduce the cost in hoes mouse control. 
Table 1. effect of astonin concentrations mixed with warfarin bait $0.025 \%$ on House Moues under laboratory condition.

\begin{tabular}{|c|c|c|c|c|c|}
\hline \multirow{2}{*}{ Bait concenters. } & \multirow{2}{*}{$\begin{array}{c}\text { Mean } \\
\text { b.w.(g) }\end{array}$} & \multirow{2}{*}{$\begin{array}{c}\text { Mortality } \\
\%\end{array}$} & \multicolumn{2}{|c|}{ Days to death } & \multirow{2}{*}{$\begin{array}{c}\text { Total bait } \\
\text { consumed (gm) }\end{array}$} \\
\cline { 4 - 5 } Warfarin & 17.2 & 50 & 11.0 & $4-18$ & 76 \\
\hline w. $+1 \%$ astonin & 18.1 & 100 & 5.0 & $1-9$ & 49.8 \\
\hline w. $+0.5 \%$ astonin & 16.8 & 100 & 6.0 & $3-9$ & 53.6 \\
\hline w. $+0.25 \%$ astonin & 17.5 & 90 & 7.0 & $2-12$ & 57.4 \\
\hline w. $+0.01 \%$ sastonin & 17.5 & 80 & 9.0 & $4-14$ & 71.2 \\
\hline
\end{tabular}

Table 2. Mortality of M. Musculus trapped from field after feeding on warfarin bait $0.025 \%$ for different periods.

\begin{tabular}{|c|c|c|c|c|c|}
\hline \multirow{2}{*}{$\begin{array}{c}\text { Feeding } \\
\text { period } \\
\text { (days) }\end{array}$} & $\begin{array}{c}\text { Mean of } \\
\text { b.w. }\end{array}$ & \multirow{2}{*}{$\begin{array}{c}\text { Mortality } \\
\%\end{array}$} & \multicolumn{2}{|c|}{ Days to death } & \multirow{2}{*}{$\begin{array}{c}\text { Mean total bait } \\
\text { intake }\end{array}$} \\
\cline { 5 - 6 } & 16.7 & - & - & - & 51 \\
\hline 3 & 18.3 & 30 & 8 & 8 & 101 \\
\hline 6 & 16.4 & 60 & $5-18$ & 11.5 & 157 \\
\hline 10 & 17.5 & 70 & $7-20$ & 13.5 & 185.7 \\
\hline 15 & 17.3 & 90 & $7-17$ & 12.0 & 192 \\
\hline 20 & 18.2 & 100 & $6-19$ & 12.5 & 201 \\
\hline
\end{tabular}
$\mathrm{LFP}_{50}=5.9$ day
$L T_{50}=9.6$ day
$\mathrm{LFP}_{90}=15.0$ day
$\mathrm{LT}_{90}=16.2$ day 
Table 3. Mortality of M. musculus trapped from houses After feeding on warfarin bait $0.025 \%$ for different periods.

\begin{tabular}{|c|c|c|c|c|c|}
\hline \multirow{2}{*}{$\begin{array}{c}\text { Feeding } \\
\text { period } \\
\text { (days) }\end{array}$} & \multirow{2}{*}{$\begin{array}{c}\text { Mean of } \\
\text { b.w. }\end{array}$} & $\begin{array}{c}\text { Mortality } \\
\%\end{array}$ & \multicolumn{2}{|c|}{ Days to death } & \multirow{2}{*}{$\begin{array}{c}\text { Mean total bait } \\
\text { intake }\end{array}$} \\
\cline { 4 - 5 } 2 & 18.3 & 10 & $0-5$ & 5 & 45 \\
\hline 3 & 18.6 & 20 & $2-12$ & 7 & 72 \\
\hline 6 & 17.2 & 60 & $4-14$ & 9 & 130 \\
\hline 10 & 16.9 & 90 & $5-12$ & 8.5 & 172 \\
\hline 15 & 18.0 & 100 & $3-16$ & 8.5 & 184 \\
\hline
\end{tabular}

$\mathrm{LFP}_{50}=4.8$ day.

$\mathrm{LT}_{50}=7.6$ day

$\mathrm{LFP}_{90}=10.8$ day

$\mathrm{LT}_{90}=10.8$ day

Table 4. Astonin efficacy mixed with warfarin bait $0.025 \%$ on filed M. musculus through different feeding period.

\begin{tabular}{|c|c|c|c|c|c|}
\hline \multirow{2}{*}{$\begin{array}{c}\text { Feeding } \\
\text { period } \\
\text { (days) }\end{array}$} & \multirow{2}{*}{$\begin{array}{c}\text { Mean of } \\
\text { b.w. }\end{array}$} & \multirow{2}{*}{$\begin{array}{c}\text { Mortality } \\
\%\end{array}$} & \multicolumn{2}{|c|}{ Days to death } & \multirow{2}{*}{$\begin{array}{c}\text { Mean total bait } \\
\text { intake }\end{array}$} \\
\cline { 4 - 5 } & 16.7 & 10 & 2 & 2 & 31 \\
\hline 2 & 17.3 & 50 & $1-9$ & 5 & 85 \\
\hline 6 & 16.2 & 80 & $1-3$ & 7 & 113 \\
\hline 10 & 18.4 & 90 & $2-9$ & $5-5$ & 120 \\
\hline 15 & 18.4 & 100 & $1-13$ & 7 & 122 \\
\hline
\end{tabular}

$\mathrm{LFP}_{50}=3.6$ day.

$\mathrm{LT}_{50}=4.0$ day .

$\mathrm{LFP}_{90}=8.5$ day

$\mathrm{LT}_{90}=8.2$ day. 
Table 5. Astonin efficacy mixed with warfarin bait $0.025 \%$ on houses M. musculus through different feeding period.

\begin{tabular}{|c|c|c|c|c|c|}
\hline \multirow{2}{*}{$\begin{array}{c}\text { Feeding } \\
\text { period } \\
\text { (days) }\end{array}$} & \multirow{2}{*}{$\begin{array}{c}\text { Mean of } \\
\text { b.w. }\end{array}$} & \multirow{2}{*}{$\begin{array}{c}\text { Mortality } \\
\%\end{array}$} & \multicolumn{2}{|c|}{ Days to death } & \multirow{2}{*}{$\begin{array}{c}\text { Mean total bait } \\
\text { intake }\end{array}$} \\
\cline { 4 - 5 } & 17.3 & 10 & 2 & 2 & 30 \\
\hline 2 & 18.0 & 60 & $2-9$ & 5.5 & 71 \\
\hline 6 & 18.2 & 80 & $1-8$ & 4.5 & 95 \\
\hline 10 & 16.0 & 100 & $1-9$ & 5 & 100 \\
\hline
\end{tabular}

$\operatorname{LFP}_{50}=3.2$ day

$\mathrm{LT}_{50}=3.4$ day .

$\mathrm{LFP}_{90}=6.3$ day

$\mathrm{LT}_{90}=6.2$ day.

Table 6. susceptibility of $M$. musculus on tow habitat at warfarin baits $0.025 \%$ or mixed with astonin $0.25 \%$.

\begin{tabular}{|c|c|c|c|c|c|}
\hline \multicolumn{2}{|c|}{ Treatment } & \multicolumn{2}{|c|}{ Houses mouse } & \multicolumn{2}{c|}{ Filed mouse } \\
\cline { 2 - 6 } & & $\begin{array}{c}\text { Warfarin bait } \\
\text { alone }\end{array}$ & $\begin{array}{c}\text { Warfarin } \\
\text { bait }+ \\
\text { Astonin }\end{array}$ & $\begin{array}{c}\text { Warfarin bait } \\
\text { alone }\end{array}$ & $\begin{array}{c}\text { Warfarin bait } \\
+ \text { Astonin }\end{array}$ \\
\hline \multirow{2}{*}{ LFP } & 50 & 4.8 & 3.2 & 5.6 & 3.6 \\
\cline { 2 - 6 } & 90 & 10.8 & 6.3 & 15.0 & 8.5 \\
\hline \multirow{2}{*}{ LT } & 50 & 7.6 & 3.4 & 9.6 & 4.2 \\
\cline { 2 - 6 } & 90 & 10.8 & 6.2 & 16.2 & 7.8 \\
\hline
\end{tabular}


Table 7. Astonin efficacy mixed with warfarin bait $0.025 \%$ on houses Musculus through different feeding period under field condition.

\begin{tabular}{|c|c|c|c|}
\hline Treated area & bait types & $\begin{array}{c}\text { Bait } \\
\text { consumption } \\
\text { gr. }\end{array}$ & $\begin{array}{c}\text { Population } \\
\text { reduction\% }\end{array}$ \\
\hline Field & Warfarin alone & 2200 & 64 \\
\hline Houses & Warfarin + Astinon & 1500 & 86 \\
\hline & Warfarin alone & 1700 & 68 \\
\hline & Warfarin + Astinon & 1000 & 91 \\
\hline
\end{tabular}

\section{REFERENCES}

1. Abdel-Azeem M., I. 2013. Behavioral and toxicological studies to overcome on some rodenticides problems. PH. Thesis Fac. Agric. Moshtohor, Banha University.

2. Buckle A.P. and R.H. Smith. 1994. Rodent pest and their control, cab international, UR.

3. Deoras, P.J., C.G. Chaturvedi; , N.E. VAJ and D.M. Ronapurkary. 1972. Tolerance shown by Rattus rattus to anticoagulant rodenticide. Proc. $5^{\text {th }}$ vert. pest. Conf., Fresno, Calif., March 7-9, 178-188.

4. Finney, D.J. 1971. Probit analysis. Cambridge Univ. press: 325-333.

5. Greaves, J.H.; B.O. Rennison and R. Redfern. 1973. Warfarin resistance in the ship rat in Liverpool. Int. Pest Control, 15-17.

6. Hussein 1991. Ecological studies and control of certain rodents in Beni-Suef governorate M.Sc. Thesis Fac. Agric. Cairo Univ.

7. Hussein, S.S.M. 1997. Relative Susceptibility of Three Rodent Species to Warfarin. Ph. Thesis, Fac. Agric. Cairo Univ.

8. Jackson, W.B and A.D. Ashton. 1980. Present distribution of anticoagulant resistance in the United States. In: vitamin $\mathrm{K}$ metabolism and vitamin $\mathrm{K}$ dependent proteins (ed. suttee, J.W.), 392-397. Univ. Park press, Baltimore.

9. Jae Y. 2011. Drug actions and interactions, 576. 
10. Kandil A.; Abdullah M.D.; H.I. El-Deeb. and W.M. Gabr. 2008. Factors affecting the susceptibility of roof rat Trapped From Different Habitat To Warfarin, Egypt J. Agric. Res., 86 (2) 413-421.

11. Khan, H.A.: A. Sohail and S.Yazdani 2000. Significance of additives to enhance poison baits acceptance against field rats in rice paddy in central Punjab, Pakistan. Int. J. Agri. Biol., 2 (1-2); 74-76.

12. Mathys, G. 1975. Guide line for the development and biological evaluation of rodenticide EPPO Bull., 5(1): 7-49.

13. Meehan, A.P. 1984. Rats and mice their biology and control, the Rentokil library, London.

14. Saunders, G.R. 1978. Resistance to Warfarin in the Roof Rat in Sidney, N.S.W. Search, 39-40.

15. World Health Organization 1982. Instructions for determining the susceptibility or resistance of rodents to anticoagulant rodenticide WHO/VBC/82, 843: 1-9. 


\title{
إضافه الاستونين لتحسين فاعلية الورفارين ضد فؤيره المنازل فى بيئتى المنازل والحقول بمحافظة بنى سويف
}

\author{
أحمد محمد رزق \\ معهر بحوث وقاية النباتات - مركز البحوث الزراعية - دقى - جيزة
}

تعبتر فؤيره المنازل من القو ارض ذات المقاومة العالية للمبيدات المانعة لتجلط فــى بــر امج

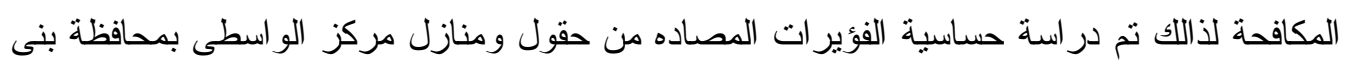

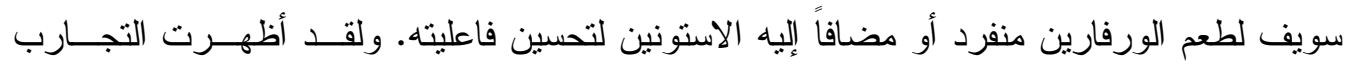

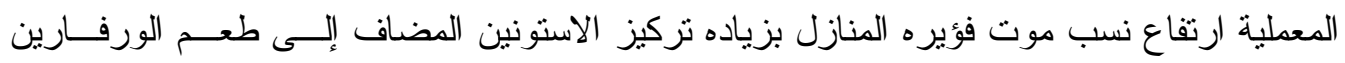

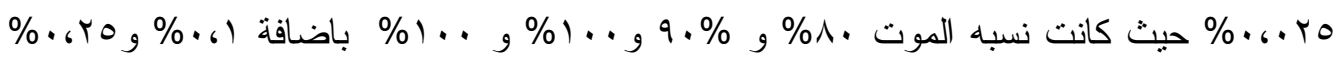

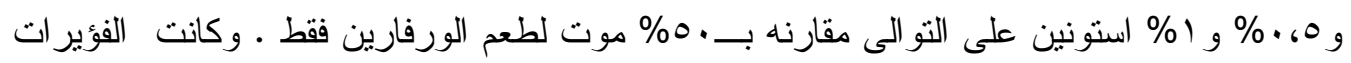

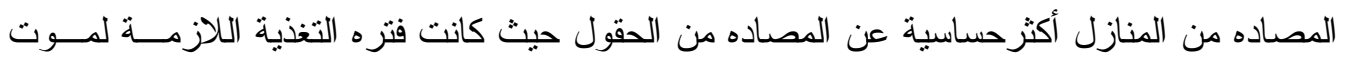

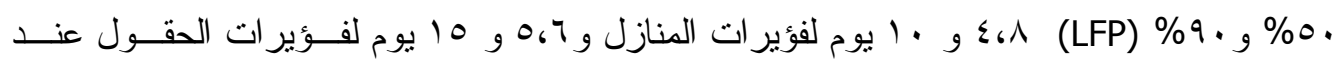

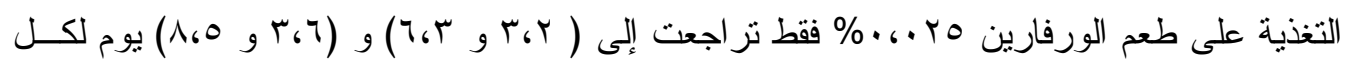

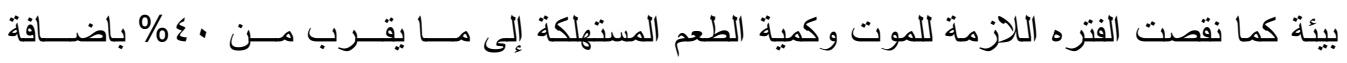

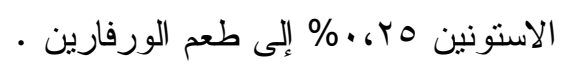

و أظهرت التجارب الحقلية لنطبيق إضافة الاستونين هץ، •\% إلى طعم الورفارين هץ •، • \% لمكافحة

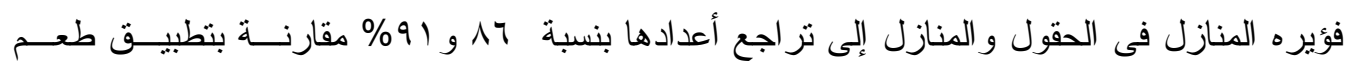

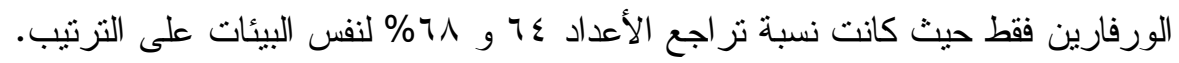
وبناءاً على النتائج المتحصل عليها يتضح أهمية إضافة الاستونين إلى المبيدات المانعة لتجلطه الــدم

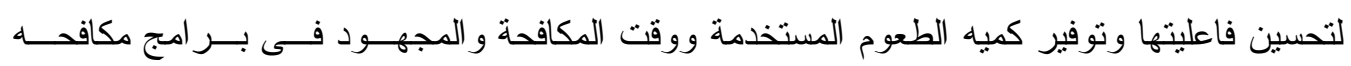

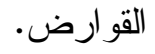

